\title{
MUTU LAYANAN AKADEMIK \\ (Studi tentang Pengaruh Pemanfaatan Fasilitas Belajar dan Kinerja Staf Program Studi terhadap Mutu Layanan Akademik Program Studi di Sekolah Pascasarjana Universitas Pendidikan Indonesia)
}

\author{
Khairul Azan \\ Dosen Universitas Pendidikan Indonesia \\ E-mail: khairulazan18@gmail.com
}

\begin{abstract}
ABSTRAK
Salah satu upaya peningkatan mutu perguruan tinggi adalah dengan memberikan layanan prima mengenai kebutuhan akademik dari setiap mahasiswa sebagai pengguna (customer) jasa perguruan tinggi. Beberapa faktor yang mempengaruhi mutu layanan akademik diantaranya adalah fasilitas belajar yang memadai dan kinerja staf dalam hal pelayanan yang sesuai dengan kebutuhan mahasiswa. Penelitian ini dilatarbelakangi oleh kesenjangan antara fenomena empiris dengan teori yang berlaku. Dimana mahasiswa seringkali tidak merasa puas dengan mutu layanan akademik yang diberikan, seperti fasilitas dan kinerja staf Program Studi yang belum sesuai dengan harapan dari mahasiswa sebagai pelanggan. Penelitian ini bertujuan untuk mendeskripsikan dan menganalisa pengaruh pemanfaatan fasilitas belajar dan kinerja staf Program Studi terhadap mutu layanan akademik Program Studi di Sekolah Pascasarjana Universitas Pendidikan Indonesia. Metode yang digunakan dalam penelitian ini adalah metode survei dengan pendekatan kuantitatif. Teknik pengumpulan data yang digunakan adalah angket. Adapun subjek yang dijadikan sampel adalah mahasiswa dari 36 Program Studi yang ada di Sekolah Pascasarjana Universitas Pendidikan Indonesia yang berjumlah 352 mahasiswa. Hasil penelitian menunjukkan bahwa gambaran umum mutu layanan akademik Program Studi di Sekolah Pascasarjana Universitas Pendidikan Indonesia berada pada kategori tinggi. Sedangkan untuk pemanfaatan fasilitas belajar berada pada kategori cukup, dan kinerja staf Program Studi berada pada kategori baik. Secara parsial pemanfaatan fasilitas dan kinerja staf Program Studi memberikan pengaruh yang signifikan terhadap mutu layanan akademik Program Studi. Begitu juga sama halnya jika dilihat secara simultan bahwa pemanfaatan fasilitas belajar dan kinerja staf Program Studi sama memberikan pengaruh yang signifikan terhadap mutu layanan akademik Program Studi.
\end{abstract}

Kata kunci: Pemanfaatan Fasilitas Belajar, Kinerja Staf Program Studi, Mutu Layanan Akademik Program Studi

\begin{abstract}
One of the efforts to improve the quality of higher education is to provide excellent service on the academic needs of each student as a user (customer) of service college. Several factor which effect the quality of academic services include adequate learning facilities and staff performance in terms of services that fit the student needs. This research is motivated by the gap between empirical phenomena and the prevailing theory, where student often do not feel satisfied with the quality of academic services provided, such as facilities and study program staff performance are not in accordance with the expectations of students as cutomers. This study aims to describe and analyze the effect of learning facilities utilization and study program staff performance towards quality of academic services for study program at the School of Postgraduate Studies Indonesia University of Education. The methode used in this study is a survey methode with a quantitative approach. The data collection technique used is a questionnaire. The sampled-subject are students from 36 existing courses at the School of Postgraduate Studies Indonesia University of Education amounting to 352 student. The result show that the general picture of the quality of academic services for study program at School of Postgraduate Studies Indonesia University of Education are in the category. As for the use of learning facilities in the fairly well category, and study program staff performance is in the good category. In partial, utilization of the facilities and study program staff performance have a significant influence on the quality of academic services for study program. So is the same as if seen that the simultaneous learning facilities utilization and study program staff performance a significant influence on the quality of academic services for study program.
\end{abstract}

Keyword: Learning Facilities Utilization, Study Program Staff Performance, Quality of Academic Services for Study Program. 


\section{PENDAHULUAN}

Perguruan tinggi sebagai salah satu bagian dari sistem pendidikan nasional yang bergerak dibidang penyedia jasa pendidikan harus mampu merespon perubahan lingkungan yang disebabkan antara lain karena meningkatnya pengetahuan masyarakat sebagai customer (pelanggan) yang ditunjukkan dengan perubahan sikap yang semakin kritis, meningkatnya kompetisi, tuntutan dunia kerja yang semakin tinggi dan perubahan teknologi yang begitu pesat.

Perubahan ini membuat persaingan yang semakin tinggi diantara perguruan tinggi. Agar mampu bersaing dan tetap bertahan maka pengelolaan berbasis mutu merupakan faktor penentu. Beberapa komponen yang bisa mempengaruhi mutu sebuah perguruan tinggi. Salah satu diantaranya ialah mutu layanan pendidikan yang diberikan institusi kepada pelanggan (mahasiswa). Sebagaimana yang dijelaskan dalam Undang-Undang Penyelenggaraan Pendidikan Tinggi No. 12 tahun 2012 Pasal 6 yang menyebutkan salah satu prinsip penyelenggaraan pendidikan tinggi yaitu "pemberdayaan semua komponen masyarakat melalui peran serta dalam penyelenggaraan dan pengendalian mutu layanan Pendidikan Tinggi”.

Layanan adalah sebuah proses pemberian jasa (service delivery) dari pemberi layanan kepada pelanggan (customer). Kualitas layanan tidak bisa dinilai dari perspektif produsen tetapi harus beranjak dari perspektif customer yaitu kepuasan pelanggan. Kepuasan pelanggan merupakan cerminan dari layanan yang bermutu. Menurut Kotler (2000, hlm. 45), kepuasan dari sisi konsumen dipandang baik apabila memenuhi apa yang mereka harapkan, sebaliknya pelayanan akan dipersepsikan buruk apabila tidak memenuhi apa yang mereka harapkan. Penjelasan tersebut mengandung makna bahwa mahasiswa dalam hal ini sebagai pelanggan di perguruan tinggi akan memandang mutu layanan sebagai perbandingan antara persepsi mereka tentang apa yang mereka terima dengan apa yang mereka harapkan.

Beberapa faktor yang dapat mempengaruhi kualitas layanan pendidikan (akdemik) yang diberikan pihak perguruan tinggi kepada mahasiswa. Hasil penelitian Astuti (2009, hlm. 11) menyebutkan tiga dimensi yang berhubungan dengan kualitas layanan dalam bentuk jasa pendidikan yaitu: (1) Respect for students (respek terhadap mahasiswa). Hal ini bisa berupa respon dalam bentuk layanan yang diberikan baik dari staf prodi maupun dosen kepada mahasiswa. Adapun layanan yang diberikan tersebut merupakan gambaran kinerja setiap individu. (2) Professor's knowledge (pengetahuan dosen), yang merupakan gambaran segala hal yang berkaitan dengan pengetahuan yang dipahami oleh dosen yang akan disampaikan kepada mahasiswa, dan (3) University physical environment (lingkungan fisik universitas atau perguruan tinggi), yang mencerminkan fasilitas-fasilitas yang tersedia baik di dalam ruang kuliah maupun di lingkungan kampus. Fasilitas yang ada di perguruan tinggi merupakan alat penunjang agar terciptanya proses pembelajaran yang efektif. Adapun yang tergolong fasilitas perguruan tingi diantaranya lahan kampus, parkir, bangunan, perpustakaan, toilet, ruang kelas, tempat ibadah, laboratorium, media pembelajaran dan lain-lain yang dianggap sebagai fasilitas di perguruan tinggi.

Dari penjelasan di atas jelaslah secara teoritis bahwa keberadaan fasilitas belajar dan kinerja staf prodi berpengaruh terhadap kualitas dari layanan pendidikan (akademik) yang diterima mahasiswa. Namun, meskipun demikian fenomena yang terjadi dari gejala yang ditemukan terlihat adanya kesenjangan antara teoritis dan praktis. Meskipun telah mendapatkan setifikat mutu, mahasiswa seringkali merasa tidak puas dengan layanan akademik yang diberikan oleh perguruan tinggi diantaranya fasilitas dan kinerja dari 
staf prodi yang masih belum sesuai dengan harapan dari para mahasiswa.

Oleh karena itu penelitian ini akan mengkaji tentang "Layanan Akademik (Studi tentang Pengaruh Pemanfaatan Fasilitas Belajar dan Kinerja Staf Prodi terhadap Mutu Layanan Akademik Prodi di Sekolah Pascasarjana Universitas Pendidikan Indonesia)"

Rumusan Masalah; (1) Bagaimana gambaran pemanfaatan fasilitas belajar di Sekolah Pascasarjana Universitas Pendidikan Indonesia?; (2) Bagaimana gambaran kinerja staf Program Studi di Sekolah Pascasarjana Universitas Pendidikan Indonesia?; (3) Bagaimana gambaran mutu layanan akademik Program Studi di Sekolah Pascasarjana Universitas Pendidikan Indonesia?; (4) Apakah ada pengaruh pemanfaatan fasilitas belajar terhadap mutu layanan akademik Program Studi di Sekolah Pascasarjana Universitas Pendidikan Indonesia?; (5) Apakah ada pengaruh kinerja staf Program Studi terhadap mutu layanan akademik Program Studi di Sekolah Pascasarjana Universitas Pendidikan Indonesia?; dan (6) Apakah ada pengaruh pemanfaatan fasilitas belajar dan kinerja staf Program Studi terhadap mutu layanan akademik Program Studi di Sekolah Pascasarjana Universitas Pendidikan Indonesia?

Kajian pustaka dalam kegiatan penelitian ini:

\section{Mutu Layanan Akademik}

Mutu layanan terbagi atas dua kata yaitu mutu dan layanan. Mutu menurut Sallis (2006, hlm. 58), adalah "sebagai sesuatu yang memuaskan dan melampaui keinginan dan kebutuhan pelanggan". Sejalan dengan pendapat di atas menurut Hoy, et al. (2000, hlm. 9), mendefisikan mutu adalah "quality in education is an evaluation of the process of educating which enhances the need to achieve and develop the talents of the customers of the process, and at the same time meets the accountability standards set by the clients who pay for the process or the outputs from the process of educating”. (kualitas pendidikan adalah evaluasi dari proses mendidik yang meningkatkan kebutuhan untuk mencapai dan mengembangkan bakat para pelanggan dari proses, dan pada saat yang sama memenuhi standar akuntabilitas yang ditetapkan oleh klien yang membayar untuk proses atau output dari proses mendidik).

Sementara itu layanan menurut Tjiptono (2004, hlm. 6), adalah "setiap tindakan yang dapat ditawarkan oleh suatu pihak kepada pihak lain, yang pada dasarnya bersifat intangible (tidak berwujud fisik) dan tidak menghasilkan kepemilikan susuatu. Produk jasa bisa berhubungan dengan produk fisik maupun tidak". Selanjutnya hal yang senada diungkapkan Lovelock \& Wright (2002, hlm. 2), yang menjelaskan "a service is an act or performance offered by one party to another although the process may be tied to a physical product, the performance is essentially intangible and does not normally result in ownership of any of the factors of production"..(layanan adalah suatu tindakan atau kinerja yang ditawarkan oleh salah satu pihak kepada pihak lain meskipun proses dapat dikaitkan dengan suatu produk fisik, kinerja pada dasarnya tidak berwujud dan biasanya tidak menghasilkan kepemilikan salah satu faktor produksi).

Dari beberapa penjelasan di atas dapat dipahami bahwa mutu layanan akademik di perguruan tinggi adalah aktivitas pemberian layanan (jasa) berupa pemenuhan segala kebutuhan akademik yang mampu memenuhi atau melebihi harapan dari setiap mahasiswa (terciptanya pembejalaran yang efektif) sebagai pelanggan di perguruan tinggi. Hal ini sejalan dengan pendapat Oldfield \& Baron (Shah, 2013, hlm. 76), menjelaskan "service quality in higher education from an organizational perspective and suggest that instead of focusing on what is important for students institutions should pay attention to what their students want". (kualitas layanan di pendidikan tinggi dari perspektif 
organisasi dan menyarankan bahwa alih-alih berfokus pada apa yang penting bagi lembaga mahasiswa harus memperhatikan apa yang siswa mereka inginkan). Selanjutnya Min \& Choon (2013, hlm. 995), menjelaskan "service quality is higher than the expected level, a customer is satisfied with the service received". (kualitas layanan lebih tinggi dari tingkat yang diharapkan, pelanggan puas dengan pelayanan yang diterima). Parasuraman, et al. (Angell, et al., 2008, hlm. 238), juga menjelaskan "service quality is a measure of how well the service level delivered, matches customer espextations" (mutu layanan adalah bagaimana layanan yang diberikan sesuai dengan espektasi pelanggan).

Beberapa indikator yang bisa digunakan dalam mengukur sebaik apa layanan akademik yang diberikan oleh perguruan tinggi kepada mahasiswa kepada mahaiswa sebagai customer. Diantaranya menurut Mosahab, et al. (2010, hlm. 77), Rasli, et al. (2012, hlm. 14), Sachdev \& Verma (2004, hlm. 111), Wang \& Shieh (2006, hlm. 200) Naik, et al. (2010, hlm. 236) dalam hasil penelitiannya masing-massing secara umum membagi dimensi kualitas layanan terdiri atas tangibles (fisik), empathy (empati), reliability (ketepatan), responsiveness (respon), dan assurance (jaminan).

\section{Pemanfaatan Fasilitas Belajar}

Lawanson, et al. (2011, hlm. 47), menjelaskan "school facilities can be defined as those things that enable the teacher to do his/her work very well and helping the learners to learn effectively". (fasilitas sekolah dapat didefinisikan sebagai hal-hal yang memungkinkan guru untuk melakukan/ pekerjaannya dengan sangat baik dan membantu peserta didik untuk belajar secara efektif).

Minarti (2011, hlm. 250), menjelaskan "sarana pendidikan, yaitu perlengkapan yang secara langsung dipergunakan untuk proses pendidikan. Prasarana pendidikan ialah fasilitas yang tidak langsung menunjang jalannya proses pendidikan". Rohiat (2010, hlm. 26), menjelaskan "sarana dan prasarana pendidikan adalah semua benda bergerak dan tidak bergerak yang dibutuhkan untuk menunjang penyeleggarakan kegiatan belajar mengajar, baik secara langsung maupun tidak langsung”. Bafadal (2004, hlm. 2), mengartikan"saranapendidikan adalah semua perangkat peralatan, bahan dan perabot yang secara langsung digunakan dalam proses pendidikan. Sedangkan prasarana pendidikan adalah semua perangkat kelengkapan dasar yang secara tidak langsung menunjang pelaksanaan proses pendidikan".

Dari pemaparan beberapa pendapat di atas dapat di pahami bahwa yang dimaksud dengan pemanfaatan fasilitas belajar adalah proses penggunaan atau pemberdayaan segala fasilitas pendidikan guna tercapainya proses pembelajaran yang efektif. Adapun fasilitas belajar dibedakan menjadi dua bentuk yaitu sarana dan prasarana pendidikan.Sarana pendidikan adalah peralatan dan perlengkapan yang secara langsung diberdayakan dalam proses belajarmengajar, seperti gedung, ruang kelas, kursi, meja serta media pengajaran. Adapun prasarana pendidikan adalah fasilitas yang secara tidak langsung menunjang jalannya proses belajar mengajar, seperti halaman, kebun, taman sekolah, lapangan sepak bola dan jalan menuju sekolah. Namun pengertian di atas bersifat fleksibel. Artinya jika prasarana ini dimanfaatkan secara langsung untuk proses belajar-mengajar seperti taman sekolah untuk mengajarkan biologi atau halaman sekolah menjadi lapangan olahraga, maka komponen tersebut berubah posisi menjadi sarana pendidikan. Ketika prasarana difungsikan sebagai sarana, berarti prasarana tersebut menjadi komponen dasar. Akan tetapi, jika prasarana berdiri sendiri atau terpisah, berarti posisinya menjadi penunjang terhadap sarana. 
Beberapa indikator yang bisa digunakan dalam melihat sebaik apa pemafaatan fasilitas belajar yang tersedia diperguruan tinggi dengan menarik kesimpulan dari beberapa pendapat diantaranya Barnawi \& Arifin (2012, hlm. 77), Rohiat (2010, hlm. 66), Arum (2007, hlm.8), dan Daryanto \& Farid (2013, hlm. 123, yaitu: 1) efektivitas pemafaatan sarana/prasarana belajar, 2) efisiensi pemanfaatan sarana/prasarana belajar

\section{Kinerja Staf Program Studi}

Suharsaputra (2010, hlm. 145), menjelaskan "kinerja merupakan suatu kemampuan kerja atau prestasi kerja yang diperlihatkan oleh seorang pegawai untuk memperoleh hasil kerja yang optimal". Karwati \& Priansa (2013, hlm. 236), menjelaskan "kinerja disebut juga dengan unjuk kerja, prestasi kerja, atau hasil pelaksanaan kerja". Bangun (2012, hlm. 231), mendefinisikan "kinerja (performance) adalah hasil pekerjaan yang dicapai seseorang berdasarkan persyaratanpersyaratan pekerjaan (job requirment)". Rivai, dkk (2005, hlm. 15), mengartikan "kinerja adalah kesediaan atau kelompok orang untuk melakukan sesuatu kegiatan dan menyerpunakannya sesuai dengan tanggungjawabnya dengan hasil seperti yang diharapkan". Wibowo (2007, hlm. 67), menjelaskan "kinerja merupakan suatu proses tentang bagaimana pekerjaan berlangsung untuk mencapai hasil kerja.

Dari beberapa pendapat di atas dapat disimpulkan bahwa kinerja staf prodi di perguruan tinggi adalah hasil kerja yang ditunjukkan oleh para staf prodi yang ada di perguruan tinggi dari pelaksanaan tugas dan tanggung jawabnya.

Beberapa indikator untuk mengukur kinerja staf prodi menurut Bangun, 2012, hlm. 234), Sutrisno (2010, hlm. 152-153), Sadarmayanti (2013, hlm. 296), Supardi (2014, hlm. 48), Hersey, et al, dalam Wibowo (2007, hlm.

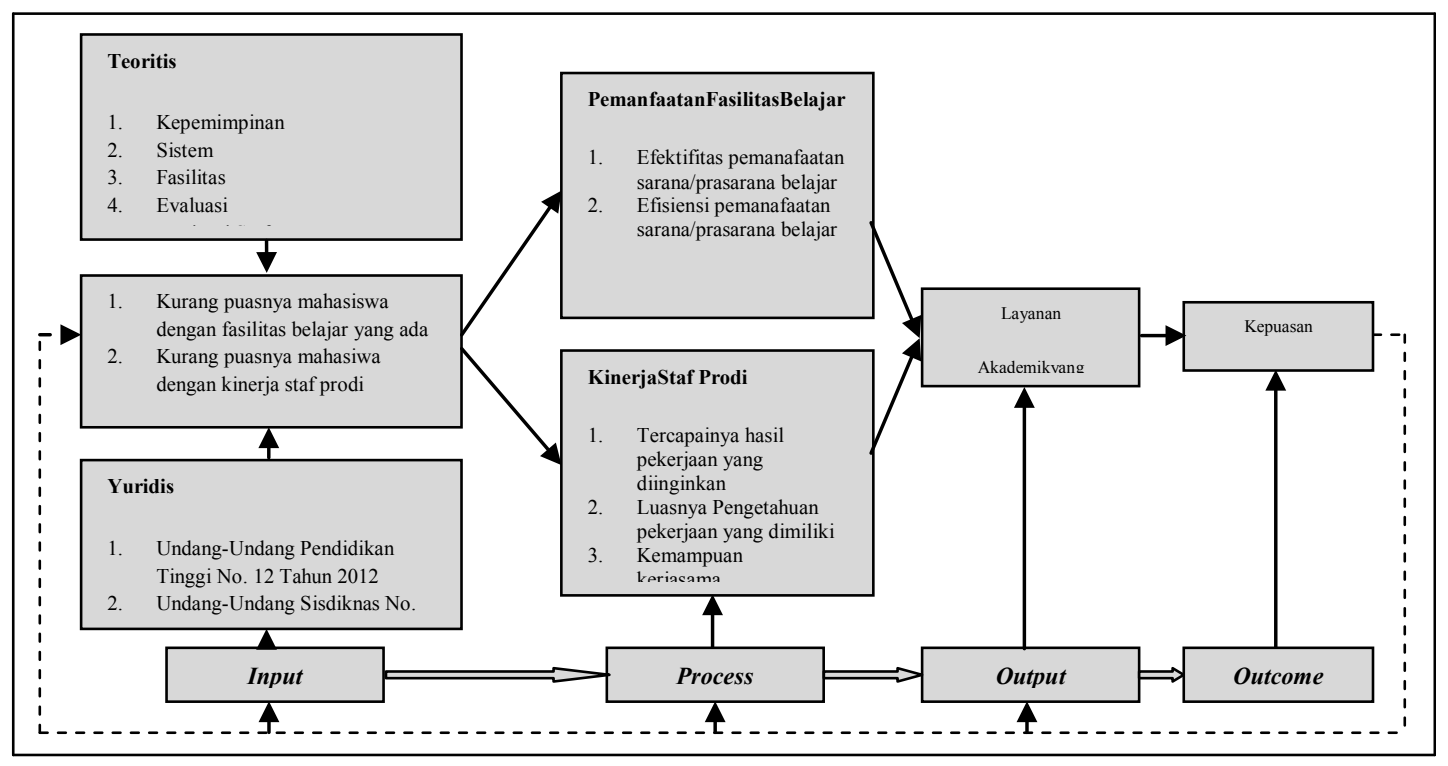

Gambar 1.

Kerang Pemikiran Penelitian

77), disimpulkan diantaranya, yaitu: 1) hasil pekerjaan 2) pengetahuan pekerjaan, 3) kemampuan kerjasama, 6) kedisiplinan

\section{Kerangka Pemikiran}

Kerangka pemikiran merupakan dasar melakukan penelitian, yang berlandaskan kepada fakta atau fenomena dilapangan, observasi dan kajian literatur. Kerangka pemikiran yang baik di didasarkan pada identifikasi variabel-variabel penting yang relevan dengan permasalahan penelitian dan mampu menjelaskan hubungan antar variabel secara logis. Oleh karena itu kerangka 
berfikir dalam penelitian ini dapat dilihat seperti gambar di bawah ini:

\section{Hipotesis Penelitian}

1. Terdapat pengaruh antara pemanfaatan fasilitas belajar terhadap mutu layanan akademik Program Studi.

2. Terdapat pengaruh antara kinerja staf Program Studi terhadap mutu layanan akademik Program Studi.

Terdapat pengaruh antara pemanfaatan fasilitas belajar dan kinerja staf Program Studi terhadap implementasi mutu layanan akademik Program Studi.

\section{METODOLOGI PENELITIAN}

Penelitian ini menggunakan metode survei dengan pendekatan kuantitatif, dengan mengembangkan dua variabel independen (Pemanfaatan Fasilitas Belajar dan Kinerja Staf Prodi), dan satu variabel dependen (Mutu Layanan Akademik Prodi).

Penelitian ini dilakukan di SPs UPI dengan unit analisisnya semua Prodi yang ada di SPs UPI. Adapun subyek penelitiannya adalah mahasiswa dengan populasi semua mahasiswa yang masih aktif dari 36 prodi dengan jumlah 4.285 mahasiswa.

Untuk menentukan jumlah sampel penulis menggunakan dua tahapan yaitu: 1) mencari sampel dari total populasi dengan menggunakan teknik random sampling. 2) mencari jumlah sampel untuk masingmasing prodi dengan menggunakan teknik proportional random sampling sehingga diperoleh 352 sampel sebagai responden.

Pengumpulan data primer dalam penelitian ini menggunakan angket yang berisikan pernyataan-pernyataan dengan lima alternatif jawaban (skala likert).

Untuk menganalisis pengaruh kausalitas antara variabel independen terhadap variabel dependen, dalam penelitian ini penulis membedakan dua kategori yaitu analisis deskriptif dan analisis hipotesis. Analisis deskriptif menggunakan rumus rata-rata
(Weighted Means Scored) dari Furqon (2011, hlm. 42).Sedangkan analisis hipotesis menggunakan rumus regresi (Hartono, 2008, hlm. 178), dengan uji $t$ untuk hipotesis parsial, dan uji $F$ untuk hipotesis parsial.

\section{HASIL PENELITIAN DAN PEMBAHASAN}

\section{Hasil Penelitian}

Hasil analisis deskriptif menunjukkan bahwa secara umum variabel Y (Mutu Layanan Akademik Program Studi) di kategorikan tinggi, dengan skor rata-rata sebesar 3,58. Untuk variabel $\mathrm{X}_{1}$ (Pemanfaatan Fasilitas Belajar) di kategorikan cukup, dengan skor rata-rata sebesar 3,36. Sedangkan variabel $\mathrm{X}_{2}$ (Kinerja Staf Program Studi) di kategorikan baik, dengan skor rata-rata sebesar 3,66.

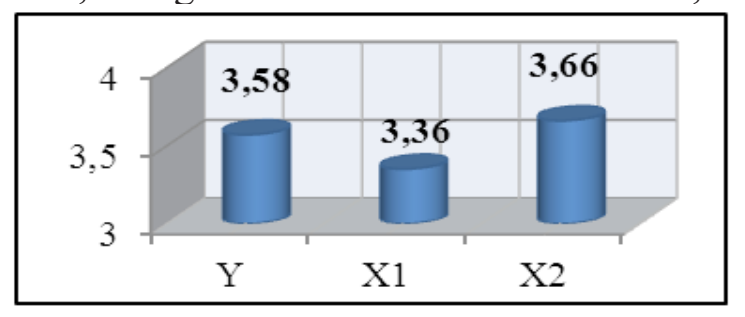

Gambar 2.

Rata-rata Setiap Variabel

Selanjutnya, hasil analisis koefisien korelasi ditemukan bahwa secara parsial pengaruh variabel pemanfaatan fasilitas belajar terhadap mutu layanan akademik Program Studi sebesar 0,466 dengan koefisien determinasi $21,7 \%$, dan pengaruh variabel kinerja staf prodi terhadap mutu layanan akademik Program Studi sebesar 0,674 dengan koefisien determinasi 45,4\%. Sedangkan secara simultan pengaruh variabel pemanfaatan fasilitas belajar dan kinerja staf prodi terhadap mutu layanan akademik Program Studi sebesar 0,717 dengan koefisien determinasi 51,4\%.

Konstanta untuk masing-masing koefisien determinasi tersebut selanjutnya ditransformasi ke dalam persamaan regresi yaitu: $\mathrm{Y}=36,136+0,170 \mathrm{X}_{1}+0,026 \mathrm{X}_{2}$ 




Gambar 3.

Struktur Pengaruh $\mathrm{X}_{1}, \mathrm{X}_{2}$ Terhadap $\mathrm{Y}$

\section{Pembahasan}

\section{Gambaran Mutu Layanan Akademik Program Studi (Y) di Sekolah Pascasarjana Universitas Pendidikan Indonesia}

Mutu layanan merupakan elemen penting dalam tercapainya pengelolaan pendidikan yang bermutu. Sebagai penyedia jasa, institusi perguruan tinggi dihadapkan dengan tuntutan harus mampu memberikan pelayanan prima kepada setiap pengguna (customer) jasa pendidikan. Sehingga dengan layanan prima (bermutu) tersebut diharapkan pelanggan akan merasa puas. Layanan prima yang diberikan tersebut tentunya dalam bentuk layanan kebutuhan akademik yang sesuai dengan kebutuhan mahasiswa sebagai pelanggan internal di perguruan tinggi. Sebagaimana yang dijelaskan Oldfield \& Baron (Shah, 2013, hlm. 76), "service quality in higher education from an organizational perspective and suggest that instead of focusing on what is important for students institutions should pay attention to what their students want". (kualitas layanan di pendidikan tinggi dari perspektif organisasi dan menyarankan bahwa alih-alih berfokus pada apa yang penting bagi lembaga mahasiswa harus memperhatikan apa yang siswa mereka inginkan).

Penelitian tentang mutu layanan akademik prodi ini dilakukan di Sekolah Pascasarjana Universitas Pendidikan Indonesia dengan jumlah responden 352 mahasiswa dari 36 program studi yang ada di SPs UPI. Dari hasil penelitian yang dilakukan diperoleh informasi yang menunjukkan bahwa mutu layanan akademik Program Studi yang diberikan kepada mahasiswa di Sekolah Pascasarjana Universitas Pendidikan Indonesia sudah tinggi. Hal ini didasarkan pada hasil perhitungan rata-rata sebesar 3,58.

Gambaran Pemanfaatan Fasilitas Belajar $\left(X_{1}\right)$ di Sekolah Pascasarjana Universitas Pendidikan Indonesia

Fasilitas belajar merupakan unsurpenting dalam proses pendidikan. Meskipun bukan menjadi hal utama namun tanpa fasilitas yang memadai proses belajar-mengajar juga tidak akan terlaksana dengan baik. Hal ini sejalan dengan pendapat Lawanson et al. (2011, hlm. 47), yang mendefisikan fasilitas belajar sebagi "school facilities can be defined as those things that enable the teacher to do his/her work very well and helping the learners to learn effectively". (fasilitas sekolah dapat didefinisikan sebagai hal-hal yang memungkinkan guru untuk melakukan/pekerjaannya dengan sangat baik dan membantu peserta didik untuk belajar secara efektif).

Penelitian tentang pemanfaatan fasilitas belajar ini dilakukan di Sekolah Pascasarjana Universitas Pendidikan Indonesia dengan jumlah responden 352 mahasiswa dari 36 program studi yang ada di SPs Universitas Pendidikan Indonesia. Dari hasil penelitian yang dilakukan diperoleh informasi yang 
menunjukkan bahwa fasilitas belajar yang bisa dimanfaatkan oleh mahasiswa sebagai customer di Sekolah Pascasarjana Universitas Pendidikan Indonesia sudah bisa demanfaatkan dengan cukup baik. Hal ini didasarkan pada hasil perhitungan rata-rata sebesar 3,36.

\section{Gambaran Kinerja Staf Program Studi $\left(\mathrm{X}_{2}\right)$ Pada Sekolah Pascasarjana Universitas Pendidikan Indonesia}

Kinerja yang optimal merupakan tuntutan yang harus dipenuhi didalam sebuah organisasi, tak terkecuali institusi pendidikan tinggi. Sebagai instutisi yang bergerak dibidang jasa maka kinerja dari setiap staf prodi yang ada diperguruan tinggi tentunya kinerja dalam hal memberikan layanan prima kepada para customer (mahasiswa). Kinerja adalah unjuk kerja dari para pekerja. Hal ini sejalan dengan pendapat Suharsaputra (2010, hlm. 145), yang menjelaskan bahwa "kinerja merupakan suatu kemampuan kerja atau prestasi kerja yang diperlihatkan oleh seorang pegawai untuk memperoleh hasil kerja yang optimal".

Penelitian tentang kinerja staf prodi ini dilakukan di SekolahPascasarjanaUniversitas Pendidikan Indonesia dengan jumlah responden 352 mahasiswa dari 36 program studi yang ada di Sekolah Pascasarjana Universitas Pendidikan Indonesia. Dari hasil penelitian yang dilakukan diperoleh informasi yang menunjukan bahwa kinerja staf prodi di Sekolah Pascasarjana Universitas Pendidikan Indonesia bisa dikatakan baik. Hal ini didasarkan pada hasil perhitungan rata-rata sebesar 3,66.

\section{Analisis Pengaruh Pemanfaatan Fasilitas Belajar $\left(\mathrm{X}_{1}\right)$ terhadap Mutu Layanan Akademik Program Studi (Y) Pada Sekolah Pascasarjana Universitas Pendidikan Indonesia}

Hasil pegolahan data terkait pengaruh antara pemanfaatan fasilitas belajar terhadap mutu layanan akademik prodi diperoleh koefisen korelasi sebesar 0,466 di taraf signifikansi $t_{\text {hitung }}(9,853)>t_{\text {tabel }}(1,9)$. Hal ini menandakan bahwa terdapat pengaruh yang signifikan antara variabel $\mathrm{X}_{1}$ (pemafatatan fasilitas belajar) terhadap Y (mutu layanan akademik prodi) dan berada pada kategori cukup kuat. Pendapat tersebut didasarkan pada kategori yang berlaku dengan perolehan nilai $\mathrm{r}_{\text {hitung }}$ sebesar 0,466 yang terletak pada interval $0,400-0,599$.

Adapun koefisien determinasi yang diperoleh dari penelitian ini adalah sebesar 21,7\%, sedangkan 78,3\% dipengaruhi oleh faktor lain (epsilon). Hal ini sejalan dengan pendapat Sallis (2006, hlm. 192) yang mengemukakan beberapa faktor yang dapat mempengaruhi mutu layanan akademik yang tidak diteliti dalam penelitian ini, diantaranya faktor kepemimpinan, strategi, sistem, evaluasi, motivasi staf.

Berdasarkan hasil analisis data tersebut maka hipotesis yang diajukan dalam penelitian ini yaitu "terdapat pengaruh antara pemanfaatan fasilitas belajar terhadap mutu layanan akademik" diterima. Hal ini juga didukung dengan beberapa hasil penelitian terdahulu diantaranya; yang dilakukan Saginova \& Belyansky (2008, hlm. 350), yang mengatakan bahwa upaya peningkatan layanan pendidikan harus didukung oleh inovasi dan pengembangan fasilitas pendidikan. Hal serupa diungkapkan Yeo (2008, hlm. 159), bahwa ia mengatakan upaya peningkatan mutu layanan harus didukung dengan tersedianya fasilitas yang dapat mendukung proses pembelajaran. Selanjutnya hasil penelitian Fernandes, et al (2013, hlm. 624) menjelasan bahwa fasilitas dan layanan yang diberikan merupakan komponen yang dapat menentukan loyalitas pelanggan. Lebih lanjut hasil penelitian Roberts (2006, hlm. 378) 5) juga menemukan bahwa ketersediaan fasilitas sekolah berhubungan terhadap lingkungan belajar. Disamping itu hasil penelitian Uline dan Moran (2008, hlm. 55) juga mengungkapkan bahwa kualitas fasilitas memiliki hubungan terhadap prestasi mahasiswa. Lebih jauh lagi 
Mahajan, et al (2014, hlm. 392), dalam hasil penelitiannya juga mengutarakan hal yang sama yang menunjukkan bahwa beberapa faktor yang dapat mempengaruhi mutu pendidikan diantaranya adalah infrastruktur. Tentunya infrastruktur yang dimaksud ialah tersedianya fasilitas belajar yang memadai. Hal ini sejalan dengan pendapat Nadiri (Fernandes, et al., hlm. 618) mengungkapkan bahwa ketersedian fasilitas fisik seperti ruang kelas dan bangunan memberikan pengaruh positif terhadap kepuasan dari mahasiswa.

\section{Analisis Pengaruh Kinerja Staf Program Studi $\left(X_{2}\right)$ terhadap Mutu Layanan Akademik Program Studi (Y) Pada Sekolah Pascasarjana Universitas Pendidikan Indonesia}

Hasil pegolahan data terkait pengaruh antara kinerja staf prodi terhadap mutu layanan akademik prodi diperoleh koefisen korelasi sebesar 0,674 di taraf signifikansi $t_{\text {hitung }}$ $(17,061)>\mathrm{t}_{\text {tabel }}(1,9)$. Hal ini menandakan bahwa terdapat pengaruh yang signifikan antara variabel $\mathrm{X}_{2}$ (kinerja staf prodi) terhadap Y (mutu layanan akademik prodi) dan berada pada kategori kuat. Pendapat tersebut didasarkan pada kategori yang berlaku dengan perolehan nilai $r_{\text {hitung }}$ sebesar 0,674 yang terletak pada interval 0,600 0,799 .

Adapun koefisien determinasi yang diperoleh dalam penelitian ini adalah sebesar $45,4 \%$, sedangkan 54,6\% dipengaruhi oleh faktor lain (epsilon). Hal ini sejalan dengan pendapat Sallis (2006, hlm. 192) yang mengemukakan beberapa faktor yang dapat mempengaruhi mutu layanan akademik yang tidak diteliti dalam penelitian ini, diantaranya faktor kepemimpinan, strategi, sistem, evaluasi, dan motivasi staf.

Berdasarkan hasil analisis data tersebut maka hipotesis yang diajukan dalam penelitian ini yaitu "terdapat pengaruh antara kinerja staf prodi terhadap mutu layanan akademik" diterima. Penelitian ini juga didukung dengan beberapa hasil penelitian diantaranya; hasil penelitian Ali (2012, hlm. 75), yang mengatakan bahwa antara kinerja dari staf akademik dengan kepuasan pelanggan (mahasiswa) memiliki hubungan positif dan signifikan. Maka dapat dipahami bahwa kepuasan pelanggan merupakan simbol dari mutu layanan akademik diperguruan tinggi. Sejalan dengan hal tersebut hasil penelitian Heffernan dan Megicks (2008, hlm. 250), juga mengungkapkan bahwa salah satu yang mempengaruhi mutu layanan akademik adalah kinerja dari bagian akademik mahasiswa. Lebih lanjut Chong dan Ahmed (2014, hlm. 41) juga mengemukakan dari hasil penelitiannya sehubungan dengan peran perguruan tinggi sebagai institusi penyedia jasa maka mutu layanan (sercive quality) yang harus dipenuhi salah satunya dari tiga komponen yang disebutkan adalah administration (administrasi).Administration berhubungan dengan segala kebutuhan administrasi yang tentunya diberikan oleh staf administrasi.

\section{Analisis Pengaruh Pemanfaatan Fasilitas Belajar $\left(X_{1}\right)$ dan Kinerja Staf Program Studi $\left(\mathrm{X}_{2}\right)$ terhadap Mutu Layanan Akademik Program Studi (Y) Pada Sekolah Pascasarjana Universitas Pendidikan Indonesia}

Hasil pegolahan data terkait pengaruh antara pemanfaatan fasilitas belajar dan kinerja staf prodi terhadap mutu layanan akademik prodi diperoleh koefisen korelasi sebesar 0,717 di taraf signifikansi $\mathrm{F}_{\text {hitung }} 184,324$ atau $0,000<0,05$. Hal ini menandakan bahwa terdapat pengaruh yang signifikan antara variabel $\mathrm{X}_{1}$ (pemanfaatan fasilitas belajar) dan $\mathrm{X}_{2}$ (kinerja staf prodi) terhadap Y (mutu layanan akademik prodi) dan berada pada kategori kuat. Pendapat tersebut didasarkan pada kategori yang berlaku dengan perolehan nilai $r_{\text {hitung }}$ sebesar 0,717 yang terletak pada interval $0,600-0,799$.

Adapun koefisien determinasi yang diperoleh dalam penelitian ini adalah sebesar 51,4\%, sedangkan 48,6\% dipengaruhi oleh faktor lain (epsilon). Hal ini sejalan dengan pendapat Sallis (2006, hlm. 192) yang mengemukakan 
beberapa faktor yang dapat mempengaruhi mutu layanan akademik yang tidak diteliti dalam penelitian ini, diantaranya faktor kepemimpinan, strategi, sistem, evaluasi, dan motivasi staf.

Berdasarkan hasil analisis data tersebut maka hipotesis yang diajukan dalam penelitian ini yaitu "terdapat pengaruh antara pemanfaatan fasilitas belajar dan kinerja staf prodi terhadap mutu layanan akademik" diterima. Penelitian ini juga didukung dengan beberapa hasil penelitian terdahulu diantaranya yaitu: Astuti (2009, hlm. 11) mengungkapkan bahwa tiga dimensi yang berhubungan dengan kualitas layanan dalam bentuk jasa pendidikan yaitu: (1) Respect for students (respek terhadap mahasiswa). Hal ini bisa berupa respon dalam bentuk layanan yang diberikan baik dari staf prodi maupun dosen kepada mahasiswa. Adapun layanan yang diberikan tersebut merupakan gambaran kinerja setiap individu. (2) Professor's knowledge (pengetahuan dosen), yang merupakan gambaran segala hal yang berkaitan dengan pengetahuan yang dipahami oleh dosen yang akan disampaikan kepada mahasiswa, dan (3) University physical environment (lingkungan fisik universitas atau perguruan tinggi), yang mencerminkan fasilitas-fasilitas yang tersedia baik di dalam ruang kuliah maupun di lingkungan kampus.

Lebih lanjut menurut Yeo (2008, hlm. 154155), aspek-aspek yang dapat mempengaruhi mutu layanan diantaranya adalah: 1) customer focus, artinya segala aktivitas dan upaya peningkatan mutu layanan harus berfokus pada kepuasan pelanggan, 2) quality course and delivery, yaitu segala aktivitas organisasi harus diarahkan pada pembelajaran berbasis mutu dan kebutuhan pelanggan, 3) quality support service, artinya dalam upaya peningkatan kualitas layanan harus didukung oleh fasilitas yang memadai.

Sejalan dengan penjelasan di atas hasil survei Sohail dan Shaikh yang dikutip oleh Wilkins dan Balakrishnan (2013, hlm. 150), juga menyebutkan beberapa faktor yang mempengaruhi kepuasan mahasiswa yang tentunya kepuasan itu sendiri adalah gambaran dari mutu layanan akademik diperguruan tinggi, diantara beberapa faktor tersebut adalah tersedianya sumber daya dan efektivitas pemanfaatan teknologi.

Hal serupa diungkapkan Chong dan Ahmed (2014, hlm. 41) dari hasil penelitiannya juga mengemukakan sehubungan dengan peran perguruan tinggi sebagai institusi penyedia jasa maka mutu layanan (service quality) yang harus dipenuhi mencangkup tiga komponen yaitu: teaching and learning (belajarmengajar), administration (administrasi) dan facilities (fasilitas). Teaching and learning berhubungan dengan proses belajar-mengajar yang dilakukan dikelas, dan administration berhubungan dengan segala kebutuhan administrasi yang tentunya diberikan oleh staf administrasi, sedangkan facilities adalah berhubungan dengan pemenuhan segala sarana dan prasarana yang dapat menunjang efektivitas pembelajaran.

\section{KESIMPULAN}

Mutu layanan akademik Program Studi yang meliputi indikator tangibles, emphaty, reliability, responsivenes, dan assurance berada pada kategori tinggi. Ini menggambarkan bahwa layanan yang diberikan kepada mahasiswa sudah bermutu.

1. Pemanfaataan fasilitas belajar yang meliputi indikator efektivitas dan efisiensi berada pada kategori cukup. Ini dapat dipahami bahwa pemanfaatan fasilitas belajar sudah berjalan dengan cukup baik.

2. Kinerja staf Program Studi yang meliputi indikator hasil pekerjaan, pengetahuan pekerjaan, kemampuan kerjasama dan kedisiplinan berada pada kategori baik. Ini menggambarkan bahwa kinerja staf prodi dalam memberikan layanan kepada mahasiswa sudah memenuhi keinginan dari setiap kebutuhan mahasiswa.

3. Pemanfaatan fasilitas belajar berpengaruh signifikan terhadap mutu layanan akademik Program Studi di Sekolah 
Pascasarjana Universitas Pendidikan Indonesia.

4. Kinerja staf Program Studi berpengaruh signifikan terhadap mutu layanan akademik prodi di Sekolah Pascasarjana Universitas Pendidikan Indonesia.

5. Pemanfaatan fasilitas belajar dan kinerja staf Program Studi secara bersama-sama berpengaruh signifikan terhadap mutu layanan akademik prodi di Sekolah Pascasarjana Universitas Pendidikan Indonesia.

Meskipun kinerja staf Program Studi berada pada kategori baik. Namun demikian haruslah tetap ditingkatkan agar kinerja staf Program Studi dalam memberikan layanan terus mengalami peningkatan sehigga dapat melayani segala kebutuhan kademik dari para mahasiswa secara maksimal.

\section{DAFTAR PUSTAKA}

Ahmed, R, \& Ali, I. S. (2012). "Implementing TQM Practices in Pakistan Higher Education Institutions". Pak. $j$. eng. technol. sci. Vol. 2. (1), 1-26.

Arum, A. S.W. (2007). Manajemen Sarana dan Prasarana Pendidikan. Jakarta: MKM.

Balakrishnan, S. M. W. S. (2013). Assessing Student Satisfaction in Transnational Higher Education. International Journal of Educational Management. Vol. 27. (2), 143-156.

Bangun, Wilson. (2012). Manajemen Sumber Daya Manusia. Jakarta: Penerbit Erlangga.

Barnawi \& Arifin, M. (2012). Manajemen Sarana dan Prasarana Sekolah. Jogjakarta: ArRuzz Media.

Chong, S.Y \& Ahmed, P. (2014). A Phenomenology of University Sercive Quality Experience. International Journal of Educational Management. Vol. 28. (1), 36-52.

Daryanto \& Farid, M. (2013). Konsep Dasar Manajemen Pendidikan di Sekolah. Yogyakarta: Gava Media.

Fernandes, C., et al. (2013). "Understanding Student Satisfaction and Loyalty in the UAE HE Sector". International Journal of Educational Management. Vol. 27. (6), 613-630.

Furqon. (2011). Statistik Terapan untuk Penelitian. Bandung: Alfabeta.

Hartono. (2008). Statistik Untuk Penelitian. Yogyakarta : Pustaka Pelajar.

Hoy, Charles., et al. (2000). Improving Quality in Education. London: Falmer Press.

Karwati, E \& Priansa, J. D. (2013). Kinerja dan Profesionalisasi Kepala Sekolah. Bandung: Alfabeta.

Kotler, P. (2008). Marketing Management. New Jersey: Prentice Hall Inc.

Lawanson, et al. (2011). "Provision and Management of School Facilities for the Implementation of UBE Programme". Journal of Educational and Social Research. Vol. 1. (4), 47-55.

Lovelock, C \& Wright, L. (2002). Principle of service marketing and management. New Jersey: Prentice Hall Inc.

Mahajan, R., et al. (2014). "Factors Affecting Quality of Management Education in India". International Journal of Educational Management. Vol. 28. (4), 379-399

Min, Sein \& Khoon, C.C. (2013). "Demographic Factors in the Evaluation of Service Quality in Higher Education: International Students' Perspective". international Review of Management and Business Research. Vol. 2. (4), 9941010 .

Minarti, Sri. (2011). Manajemen Sekolah (Mengelola Lembaga Pendidikan Secara Mandiri). Jogjakarta: Ar-ruzz Media.

Mosahab, R., et al. (2010). "Service Quality, Customer Satisfaction and Loyalty: A Test of Mediation". International Business Research. Vol. 3. (4), 72-80.

Naik, K. N. C., et al. (2010) "Service Quality (Servqual) and its Effect on Customer Satisfaction in Retailing". European Journal of Social Sciences. Vol. 16. (2), 231-243.

Rasli, et al. (2012). "Perception of Service Quality in Higher Education: Perspective of Iranian Students in Malaysian Universities “. International Journal of Academic Research in Management (IJARM). Vol. 1. (1), 10-25. 